\title{
MIGRAÇÕES INTERNACIONAIS DE E PARA O BRASIL CONTEMPORÂNEO volumes, fluxos, significados e políticas
}

\author{
Neide Lopes Patarra
}

\begin{abstract}
Resumo: Os movimentos migratórios internacionais a partir de e para o Brasil constituem, hoje, uma importante questão social, que envolve grupos sociais específicos, majoritariamente não documentados, sujeitos à ação de aproveitadores. A questão das remessas também tem sido alvo de especulação e iniciativas governamentais. Essa situação demanda - urgentemente - reformulação e implementação de políticas de imigração e de emigração, bem como ações voltadas à implementação dos direitos humanos dos migrantes. Palavras-chave: Migrações internacionais. Remessas. Políticas sociais.
\end{abstract}

\footnotetext{
Abstract: International migratory movements from and to Brasil nowadays constitutes an increasingly important social question. It involves specific social groups, mainly non documented persons; submitted to the action of speculators; remittances is also gaining space. It requires an urgent reformulation as well as an implementation of public in-migration and out-migration policies as well as policies related to migrants human rights and access to social services.

Key words: International migration. Remittances. Public Policies.
}

$\mathrm{D}$ esde quando se tornou manifesto, há mais de três décadas, o fenômeno da migração de brasileiros para países desenvolvidos vem-se constituindo, de maneira crescente, em tema relevante na produção científica, nas discussões políticas, na mídia falada e escrita, no cancioneiro popular e, mais recentemente, em novela de âmbito nacional.

Por outro lado, a publicação dos resultados amostrais do Censo Demográfico de 2000, as séries de informações levantadas pelo Ministério de Relações Exteriores e, principalmente, a turbulência dos primeiros anos do novo milênio passaram a reforçar a necessidade de reflexão, de realização de um balanço do conhecimento e de incorporação de novas evidências empíricas sobre a inserção do Brasil nos movimentos internacionais de população.
A crescente importância das migrações internacionais no contexto da globalização tem sido, na verdade, objeto de um número expressivo de contribuições importantes, de caráter teórico e empírico, que atestam sua diversidade, significados e implicações. Parte significativa desse arsenal de contribuições importantes volta-se à reflexão sobre as enormes transformações econômicas, sociais, políticas, demográficas e culturais que se processam em âmbito internacional, principalmente a partir dos anos 80 . Como eixo de reflexão, situam-se as mudanças advindas do processo de reestruturação produtiva ${ }^{1}$ - o que implica novas modalidades de mobilidade do capital e da população em diferentes partes do mundo. ${ }^{2}$

No cenário da globalização, as recentes tendências de movimentos migratórios internacionais também vêm 
demandando a reavaliação de paradigmas para serem melhor conhecidas e entendidas. Para tanto, tornam-se imprescindíveis a incorporação de novas dimensões explicativas e uma revisão da própria definição do fenômeno migratório. $^{3}$

Hoje, é extremamente importante considerar o contexto de luta e compromissos internacionais assumidos em prol da ampliação e efetivação dos Direitos Humanos dos migrantes. É preciso reconhecer o novo, difícil e conflitivo papel dos Estados Nacionais e das políticas sociais em relação aos processos internacionais e internos de distribuição da população no espaço - cada vez mais desigual e excludente. Há que se tomar em conta as tensões entre os níveis de ação internacional, nacional e local. É de fundamental importância considerar que os movimentos migratórios internacionais constituem a contrapartida da reestruturação territorial planetária - que, por sua vez, está intrinsecamente relacionada à reestruturação econômicoprodutiva em escala global.

Além disso, acontecimentos recentes, como o 11 de setembro nos Estados Unidos e sua estratégia militar preventiva iniciada com a Guerra do Iraque, os conflitos do Oriente Médio, as tensões entre comunidades de imigrantes muçulmanos na Europa, entre outras manifestações das contradições e conflitos que permeiam a vida coletiva neste início de século, reforçam as dimensões de racismo e xenofobia.

No plano internacional, este é o momento decisivo para a definição de quais países terão acesso ao desenvolvimento. Em outras palavras, é importante saber quais deles poderão lograr o desenvolvimento econômico e social capaz de tirá-los da condição de eternos países em desenvolvimento. Nesse cenário, comparecem os países da América do Sul, onde, nas décadas passadas - com exceções, mas de um modo geral - assistiu-se a processos de democratização, embora as crises financeiras, o déficit fiscal, as dívidas externas e internas, o estancamento do processo produtivo, entre outras dimensões, tenham imprimido como contrapartida dessa dinâmica, o aumento da pobreza, da desigualdade e da exclusão, distanciandoos ainda mais dos países do Primeiro Mundo.

Para superar a distância que a separa dos países desenvolvidos, a América do Sul desenvolve estratégias - e muitas vezes oscila entre a obediência aos cânones neoliberais e as tentativas de incrementar o resgate social acumulado. Nesse contexto move-se o Mercosul, que já há mais de uma década opera com oscilações, contradições e desafios, ao mesmo tempo que as discussões sobre comércio internacional e a Alca recrudescem ainda mais os conflitos internos específicos da região.

Como estratégia de enfrentamento da situação adversa, a conjuntura política aponta para a emergência de lideranças mais voltadas ao reforço regional conjunto do continente sul-americano. Por essa razão, no âmbito do Mercosul, a política externa do atual governo parece estar dirigida ao fortalecimento do bloco de integração ampliado. Também o presidente Kirschner, na Argentina - país rival, mas também aliado - parece favorecer maior dinamismo e um avanço relativo nas políticas sociais que envolvem diretamente aqueles que se movimentam internamente nos países do bloco. Esses deslocamentos se dão tanto por mudança de residência; como por retorno a situações precárias anteriores; circularidade; dupla residência ou permanências temporárias. Isso ocorre com famílias ou individualmente - com aumento da participação de mulheres - e muitas vezes envolvem ações ilegais ou clandestinas.

\section{MODALIDADES DE MOVIMENTOS, SIGNIFICADOS E GRUPOS SOCIAIS ENVOLVIDOS}

Na mídia, há reportagens, quase diariamente, sobre brasileiros que migraram e vivem em outros países - particularmente nos Estados Unidos. O tema também foi tratado em telenovela recentemente transmitida em "horário nobre". Esses dois exemplos, entre outras evidências, ilustram a crescente visibilidade do tema; a consolidação de fluxos migratórios; os procedimentos adotados para a entrada nos Estados Unidos - agora via México -; os riscos que os migrantes correm; a violência e a corrupção dos atravessadores; a mescla destes com o narcotráfico; o tratamento desigual para os "migrantes documentados" e os chamados "migrantes irregulares".

Cobertura jornalística recente tratou de várias dimensões dessas novas tendências e características do movimento de brasileiros rumo ao Primeiro Mundo. Foram narradas as vicissitudes, dificuldades, desproteção, injustiças e até algum sucesso que cercam a vida cotidiana de um grupo crescente - principalmente de jovens urbanos -, que parte de uma também crescente diversidade de locais. Todos buscam inserir-se, de forma temporária ou posteriormente em caráter definitivo, no país que, para eles, parece ser o "sonho americano" (SALES, 2005; HARAZIM, 2005; MEDEIROS, 2005).

Há que se ressaltar, pelo oportuno, que na mesma edição do jornal publica-se reportagem a respeito dos recen- 
tes imigrantes sul-americanos pobres, principalmente bolivianos, que adentram o país também em busca de melhores condições de vida, aspirando a ter direitos à saúde e educação, mesmo como imigrantes também "ilegais" (CAFARDO, 2005).

No mesmo dia, a Revista da Folha também se ocupou com uma ampla cobertura a respeito dos imigrantes pobres que vieram recentemente ou que estão há mais tempo no Brasil. Relata suas vicissitudes, sua desproteção, suas condições absolutamente precárias de habitação e remuneração, a situação de seus filhos, entre outras dimensões.

Dez anos antes, em sua edição de outubro de 1995, o jornal $O$ Estado de S.Paulo anunciava em manchete de primeira página, em letras garrafais: "Brasil exportou um milhão de migrantes" (RABINOVICH, 1995). O autor da matéria estampava em "furo jornalístico" os números que estavam sendo debatidos num seminário em Brasília: tratava-se de um arredondamento de cifras projetadas mediante o uso do Censo Demográfico de 1991 (CARVALHO, 1996; OLIVEIRA et al., 1996). Ultrapassar a cifra de um milhão parecia a configuração plena de uma nova questão social.

Nos debates e nas publicações que se seguiram, estavam presentes algumas características percebidas a respeito de um fenômeno que estava se configurando pela primeira vez na história do país, ferindo os brios nacionalistas e a imagem de país receptor: a saída de brasileiros para o exterior. ${ }^{4}$ Delineava-se, também, no conjunto de contribuições, os entendimentos e os significados não só de saída de brasileiros como da entrada de novos imigrantes.

Num resumo a respeito dos entendimentos e dessas interpretações, cumpre ressaltar alguns pontos que permanecem como contribuições imprescindíveis para o debate atual:

- os movimentos migratórios internacionais de e para o Brasil foram percebidos como inseridos na reestruturação produtiva em nível internacional. Assim, a crise financeira, o estancamento do processo de desenvolvimento, o excedente de mão-de-obra crescente, a pobreza, a ausência de perspectiva de mobilidade social, entre outras causas, estariam na raiz da nova questão social;

- percebia-se não se tratar de uma inversão de tendência - o Brasil não seria um país de imigração que passou a ser de emigração. Em outras palavras, não teria passado de receptor a expulsor de população. O contexto, o significado, os volumes, os fluxos, as redes e outras dimensões importantes, no contexto interno e internacional, pas- savam a ser completamente distintos de tudo o que, sob a mesma rubrica, sucedera no passado. Embora em menor escala, o contexto dos movimentos internacionais que envolviam o Brasil indicava a entrada de novos contingentes de estrangeiros, com características absolutamente distintas das dos movimentos anteriores;

- com exceção do caso dos "brasiguaios", percebia-se que os migrantes não eram os mais pobres - em sua maioria, os movimentos estavam atingindo os jovens adultos de camadas médias urbanas;

- ao contrário de algumas análises conjunturais que associavam a saída de brasileiros à década perdida (anos 80) ou à conjuntura do Governo Collor, esse estudo caracterizava a questão social como inerente à nova etapa da globalização e afirmava que, portanto, esta tinha "vindo para ficar";

- percebia-se que, sob a rubrica migração internacional aglutinavam-se processos e fenômenos distintos. Estes envolviam tanto questões fundiárias não resolvidas (como no já tradicional caso das migrações Brasil-Paraguai), quanto percepções e anseios de grupos sociais específicos frente a uma mobilidade social truncada no país (como no caso do "rumo ao Primeiro Mundo"), com tarefas remuneradas de baixa qualificação e manuais, porém muito melhor remuneradas. Percebiam-se modalidades de movimentos populacionais emergentes no contexto do capitalismo internacional e próprias da globalização atual como a configuração do mercado dual da economia, a entrada de pessoal técnico-científico qualificado, situações de "fuga de cérebros", entre outras;

- embora de diminuta expressão numérica, a entrada e saída de pessoas do território nacional nunca cessou. Poder-seia dizer que o Brasil beneficiou-se da "invasão de cérebros" vindos de países vizinhos, em grande parte dos quais afugentados pelos regimes autoritários dos anos 70, bem como a entrada de europeus, nos anos que se seguiram à Segunda Guerra Mundial - que são, entre outros, exemplos de pequeno, mas intermitente afluxo de estrangeiros;

- finalmente, percebia-se a emergente questão das remessas - as transferências unilaterais no balanço de pagamentos do Brasil - que já se apresentavam em expansão. Na verdade, essas remessas cresceram expressivamente nos anos 90 e tiveram como pico o ano de 1992: de 834 milhões de dólares, em 1990, passaram para 1.556 bilhão, em 1991; 2.243, em 1992; 1.653, em 1993; 2.588, em 1994; e 3.076 bilhões de dólares, em 1995 (KLAGSBRUNN, 1996, p. 45). 
Em síntese, no primeiro balanço a respeito dos movimentos internacionais contemporâneos no Brasil delinearam-se modalidades distintas e específicas, com envolvimento de distintos grupos sociais - o que, como consequiência, demandou um tratamento distinto na esfera das políticas migratórias, na esfera das políticas sociais voltadas aos migrantes e, no geral, de ações bilaterais de proteção de seus direitos. Percebia-se nitidamente a modalidade de movimento rumo aos Estados Unidos, ao Japão, a países europeus - principalmente Itália, Alemanha e posteriormente Portugal e Espanha. Também já se percebia que o movimento que mais crescia era o direcionado aos Estados Unidos, onde as primeiras comunidades de brasileiros já iam se constituindo. O entendimento da emergência da migração internacional contemporânea não excluía, é claro, a consideração da circularidade que envolve grande parte dos deslocamentos populacionais, nos quais, entre outras dimensões, as redes que se criam propiciam e reforçam a continuidade dos fluxos que vão se estabelecendo.

\section{ESTIMATIVAS E TENDÊNCIAS DOS FLUXOS MIGRATÓRIOS DE E PARA O BRASIL}

\section{Saída de Brasileiros}

As primeiras estimativas quanto à saída de brasileiros variaram, de acordo com os procedimentos utilizados, de um saldo migratório mínimo de 1.042 milhão a um máximo de 2.480 milhões de pessoas (CARVALHO, 1996) e em torno de 1,3 milhão de pessoas (OLIVEIRA et al.,
1996). Surpreendentemente, essas estimativas aproximavam-se dos registros que se iniciaram em 1996, levantados pelo Ministério de Relações Exteriores junto aos consulados e embaixadas brasileiras. De acordo com esses documentos, o total de brasileiros registrados no exterior era de 1.419.440 em 1996, elevando-se para 1.887.895 em 2000 e 2.041.098 em 2002, com ligeiro declínio em 2003, ano em que foram registrados 1.805 .436 brasileiros vivendo fora do país. ${ }^{5}$

Embora tratando-se de um registro de informações específicas, sua seqüência permite apreender algumas características e tendências. Em primeiro lugar, pode-se constatar que não se trata de "levas" de emigrantes, de "diáspora brasileira" ou outros termos freqüentemente usados pela imprensa e mesmo em alguns meios acadêmicos para referirem-se à questão social da saída de brasileiros. Mais que isso, os dados permitem levantar a hipótese da circularidade, comprovada por depoimentos e pesquisas qualitativas e reforçada pela constatação da existência de redes consolidadas - como, por exemplo, no caso do Japão, e, mais recentemente, de atravessadores que induzem a busca do "sonho americano" a preços que variam de 10.000 a 20.000 dólares. Se considerarmos que estimativas da ONU dão conta de 175 milhões de migrantes ao redor do mundo, percebe-se que é ínfima a parcela de brasileiros no contexto internacional contemporâneo das migrações internacionais. A Tabela 1 resume os dados obtidos, de acordo com o país de destino, nos anos mencionados.

Desde o início do movimento de brasileiros rumo ao Primeiro Mundo, os Estados Unidos têm sido o principal

TABELA 1

Estimativas de Brasileiros Residentes no Exterior 1996-2003

\begin{tabular}{|c|c|c|c|c|c|c|c|c|}
\hline \multirow{2}{*}{ País / Região } & \multicolumn{2}{|c|}{1996} & \multicolumn{2}{|c|}{$2000(1)$} & \multicolumn{2}{|c|}{2001} & \multicolumn{2}{|c|}{2003} \\
\hline & №s Absolutos & $\%$ & №s Absolutos & $\%$ & №s Absolutos & $\%$ & №s Absolutos & $\%$ \\
\hline Total & 1.419 .440 & 100,00 & 1.887 .895 & 100,00 & 2.041 .098 & 100,00 & 1.805 .436 & 100,00 \\
\hline Estados Unidos & 580.196 & 40,87 & 799.203 & 42,33 & 894.256 & 43,81 & 713.067 & 39,50 \\
\hline Paraguai & 350.000 & 24,66 & 454.501 & 24,07 & 369.839 & 18,12 & 310.000 & 17,17 \\
\hline Japão & 262.944 & 18,52 & 224.970 & 11,92 & 262.510 & 12,86 & 269.256 & 14,91 \\
\hline Europa & 135.591 & 9,55 & 197.430 & 10,46 & 332.164 & 16,27 & 291.816 & 16,16 \\
\hline Outros da América do Sul & 49.444 & 3,48 & 37.915 & 2,01 & 91.649 & 4,49 & 111.705 & 6,19 \\
\hline Outros & 41.265 & 2,91 & 173.876 & 9,21 & 90.680 & 4,44 & 109.592 & 6,07 \\
\hline
\end{tabular}

Fonte: Ministério de Relações Exteriores. Registros Consulares. Brasilia.

(1) O registro de brasileiros, no caso da América do Sul, nesse ano inclui apenas Argentina e Paraguai. 
país recebedor, registrando aproximadamente 580 mil brasileiros em 1996, 800 mil já em 2000, 894 mil em 2001 e 713 mil em 2003. ${ }^{6}$ Esse país tem sido, de fato, o destino de um expressivo volume de brasileiros, em sua maioria jovens e pertencentes à classe média, que entram clandestinamente e se ocupam em trabalhos não qualificados que, ao contrário do que aconteceria em seus países de origem, propiciam-lhes um orçamento maior e a possibilidade de formar uma certa poupança.

Ocorre que, possuindo um perfil diferenciado dos demais migrantes clandestinos (MARTES, 1999), os brasileiros encontram espaço para assumir trabalhos secundários, tais como balconistas, garçons, serviços domésticos e afins - trabalhos esses que são rejeitados pelos brancos e muitas vezes não são acessíveis aos negros. Outro aspecto desse fenômeno é que de fato esses migrantes se sujeitam a um rebaixamento de seu status social em prol da recompensa financeira imediata, uma vez que, no Brasil, a falta de oportunidade de emprego e o longo período de recessão econômica bloqueiam sua ascensão social. Assim, a imigração torna-se uma boa estratégia econômica, a partir da qual as redes de relações são formadas e fortalecidas e fomentam ainda mais o fluxo migratório. Há uma verdadeira "explosão" de migrantes brasileiros que, mediante a compra de um "pacote", tentam passar pelas fronteiras do México, vivendo situações arriscadas e muitas vezes violentas, nessa travessia rumo ao país de seus sonhos. De acordo com a imprensa, uma vez cruzada a fronteira, não serão presos e, com "jeitinho", acabam ficando por lá: uns, amealhando os dólares para investir no Brasil; outros, para residir permanentemente fora de casa (SALES, 2005).

Já a emigração brasileira para a Europa deve-se, em grande parte, a fatores históricos e culturais decorrentes do próprio processo migratório brasileiro que, até pouco tempo atrás, caracterizava-se como receptor de população, com predominância dos fluxos provenientes de Portugal, Espanha, Itália, Alemanha, entre outros. De um modo geral, o perfil dos emigrantes que se dirigem à Europa assemelha-se ao dos que se dirigem aos Estados Unidos, embora, neste caso, parece que traços culturais constituem dimensão importante na decisão de migrar. A isso se soma, em quantidade difícil de mensurar, a emigração de mulheres que para lá se dirigem muitas vezes iludidas, em busca de sua inserção em atividades de lazer, ou entrando na prostituição; atividades domésticas são também um possível atrativo; e a crescente saída dos jogadores de futebol, apesar de quantitativamente menos representativa, também tem sua dimensão simbólica (PATARRA; BAENINGER, 2001). Os principais países receptores são a Itália, com 16.775 pessoas em 1996, 65.196 em 2002 e 35 mil em 2003; Portugal, com 22.068 pessoas em 1996, 50.431 em 2001 e 70 mil em 2003; Espanha, com 12.026 em 1996, 13.371 em 2001 e 32 mil em 2003.

Outro fluxo de emigrantes com características históricas decorrentes do processo migratório do início do século 20 é o de trabalhadores brasileiros descendentes de imigrantes japoneses em direção ao Japão (SASAKI, 1998). Nesse caso, ocorre a fusão dos aspectos principais dos fluxos anteriores: embora sempre movidos por estratégias econômicas, os traços culturais e étnicos, bem como a rede de parentesco, são componentes decisivos na configuração e dinâmica do fluxo migratório (PATARRA; BAENINGER, 2001). Constituindo-se no terceiro país na hierarquia dos "recebedores", o Japão comparece com estimativas que vão de aproximadamente 263 mil pessoas, em 1996; 224 mil, em 2000; 262 mil, em 2001; a 269 mil, em 2003.

O país que tem permanecido como o segundo na hierarquia de recebedores constitui uma modalidade completamente distinta dos mencionados fluxos rumo ao Primeiro Mundo. Os movimentos recentes das correntes migratórias que transitaram e ainda transitam na divisa entre o Brasil e o Paraguai estão intrinsecamente relacionados à constituição da fronteira entre esses dois países, principalmente no que diz respeito às suas fronteiras agrícolas. Historicamente, essa fronteira foi marcada por uma série de lutas e batalhas que abrangiam não só os Estados nacionais como também as populações locais e as grandes empresas comerciais. Em período recente, a construção da hidroelétrica, a extensão urbana de imigração de brasileiros no Paraguai e a extensão do contrabando e do narcotráfico consolidaram a configuração de uma área de conflitos, mas também de estruturação dos translados entre as populações dos dois países. Assim, certa troca e retorno de brasileiros apenas evidencia a dinâmica iniciada principalmente nos anos $60 .^{7} \mathrm{O}$ registro de brasileiros no Paraguai indica, em 1996, 350 mil pessoas, passando para 454.501 em 2000, declinando para 262.510 em 2001, e 269 mil em 2002, elevando-se novamente em 2003, com 325.400 brasileiros registrados nos diversos consulados.

\section{Entrada de Estrangeiros}

No que concerne à entrada de estrangeiros no país, os dados censitários ainda apresentam maior dificuldade de 
estimativa: realmente, esta é uma tarefa desafiadora. Ao longo do século 20, pôde-se verificar um forte declínio em sua participação no total da população, considerandose o total de estrangeiros residentes no país nos levantamentos censitários - o chamado "estoque de imigrantes". Nas últimas décadas do século, eles atingiam um total de 912 mil em 1980, decrescendo para $767.781(0,52 \%$ da população total do país) em 1991, e 651.226 (0,38\%) em 2000 (Tabela 2). Na verdade, grande parte desse contingente é formada pelos sobreviventes dos grandes fluxos das etapas anteriores (PATARRA; BAENINGER, 2004b).

TABELA 2

População Estrangeira e População Total Brasil - 1900-2000

\begin{tabular}{cccc}
\hline Ano & $\begin{array}{c}\text { População Estrangeira } \\
\text { (Nos Absolutos) } \\
\text { (A) }\end{array}$ & $\begin{array}{c}\text { População Total } \\
\text { Brasil (№s Absolutos) } \\
\text { (B) }\end{array}$ & $\begin{array}{r}\text { Proporção de } \\
\text { Estrangeiros } \\
\text { (A/B) (\%) }\end{array}$ \\
\hline 1900 & 1.074 .511 & 16.364 .923 & 6,16 \\
1920 & 1.565 .961 & 29.069 .644 & 5,11 \\
1940 & 1.406 .342 & 39.752 .213 & 3,42 \\
1950 & 1.214 .184 & 50.730 .213 & 2,34 \\
1970 & 1.229 .128 & 91.909 .909 & 1,32 \\
1980 & 912.848 & 118.089 .858 & 0,77 \\
1991 & 767.781 & 146.825 .475 & 0,52 \\
2000 & 651.226 & 169.799 .170 & 0,38 \\
\hline
\end{tabular}

Fonte: IBGE. Censos Demográficos 1900 a 2000.

Os dados censitários também permitem observar a entrada de novos imigrantes em seus respectivos períodos intercensitários. Nas duas últimas décadas do século 20, verifica-se a entrada de 89.235 pessoas no período 19811991 e 98.514 pessoas no período 1990 e 2000 (Tabela 3).

Constata-se, também, a entrada de novos contingentes de estrangeiros, embora em volumes bem mais reduzidos do que no passado. O Censo Demográfico 1991 registra uma população estrangeira de 606.631 pessoas - o que corresponde a $0,41 \%$ da população residente no país; o de 2000, com ligeira elevação pela entrada de novos migrantes, registra 683.380 pessoas - mesmo assim, corresponde a apenas $0,40 \%$ de seu total populacional. Essas cifras, sem dúvida, subestimam o contingente de imigrantes que entra no país nos períodos intercensitários (Tabela 2).

Os países de nascimento desse contingente que passou a residir no Brasil nessas décadas estiveram concentra- dos no Mercosul Ampliado, ${ }^{8}$ respondendo por cerca de $40 \%$ dos imigrantes internacionais, seguidos dos imigrantes da Europa (mais de 20\%), Ásia (12,5\%) e América do Norte $(9,1 \%)$. Essas evidências indicam, por um lado, que o país aumentou sua inserção nas migrações do Mercosul; por outro, houve uma relativa retomada das migrações de ultramar, com fluxos de Europa e Ásia. Ressalte-se ainda que a imigração internacional norte-americana recente está relacionada à alocação temporária de mão-de-obra qualificada $^{9}$ (PATARRA; BAENINGER, 2004a; 2004b).

Além disso, informações recentes sobre pedidos de concessão de vistos específicos do Ministério do Trabalho e Emprego no Brasil revelam que, entre 1993 e 1996, foram concedidas 45.827 autorizações; entre 1997 e 1999 foram concedidas 49.888; e, entre janeiro e junho de 2000 , foram concedidas 9.496 autorizações - a maior parte das quais a estrangeiros de países europeus (mais de 30\%) seguidas de autorizações a pessoas oriundas dos Estados Unidos e Canadá, em torno de 20\% (BAENINGER; LEONCY, 2001). Esses dados estão permitindo trabalhar com a hipótese da configuração de um mercado dual de imigrantes: com os pobres não documentados - oriundos principalmente de países sul-americanos - e, em menor número, imigrantes documentados, mão-de-obra qualificada, empresários e pessoal de ciência e tecnologia - de origem européia e americana.

A Pastoral do Migrante trabalha, hoje, com uma estimativa de 1,8 milhão de estrangeiros no país; esse dado contrasta fortemente com as informações do Ministério da Justiça. Neste caso, o número estimado de estrangeiros teria, após uma estabilidade de dez anos, baixado de 1 milhão para 830 mil, e São Paulo concentraria mais da metade desse total: 440 mil, seguido do Rio, com quase 200 mil (O Estado de S.Paulo, 20 maio 2005, Caderno Vida, p. A-22).

\section{POLÍTICAS MIGRATÓRIAS E POLÍTICAS SOCIAIS NO TRATO COM MIGRANTES INTERNACIONAIS}

A Conferência Internacional sobre População e Desenvolvimento, realizada em 1994 no Cairo, na seqüência de Conferências da ONU nos anos 90, da qual o Brasil é signatário, apresenta, no capítulo X de seu Programa de Ação, a questão das migrações internacionais. ${ }^{10}$

$\mathrm{Na}$ formulação da problemática, o documento considera as migrações internacionais contemporâneas interrelacionadas ao processo de desenvolvimento, destacando a pobreza e a degradação ambiental, aliadas à ausência 
TABELA 3

População Imigrante Internacional, segundo País de Nascimento

Brasil - 1981-2000

\begin{tabular}{|c|c|c|c|c|c|}
\hline \multirow[t]{2}{*}{ País de Nascimento } & \multicolumn{2}{|c|}{$\begin{array}{c}\text { Imigrantes } \\
\text { (№s Absolutos) }\end{array}$} & \multicolumn{2}{|c|}{$\begin{array}{c}\text { Distribuição Relativa } \\
(\%)\end{array}$} & \multirow{2}{*}{$\begin{array}{c}\text { Incremento Relativo } \\
(\%)\end{array}$} \\
\hline & $1981-1991$ & $1990-2000$ & $1981-1991$ & $1990-2000$ & \\
\hline TOTAL & 89.235 & 98.514 & 100,00 & 100,00 & 9,42 \\
\hline Mercosul & 18.303 & 23.068 & 20,51 & 23,41 & 20,56 \\
\hline Argentina & 8.879 & 8.005 & 9,95 & 8,12 & $-10,92$ \\
\hline Paraguai & 5.319 & 11.692 & 5,96 & 11,86 & 54,51 \\
\hline Uruguai & 4.105 & 3.371 & 4,60 & 3,42 & $-21,77$ \\
\hline Mercosul Ampliado & 35.747 & 37.727 & 40,06 & 38,30 & 5,25 \\
\hline Argentina & 8.879 & 8.005 & 9,95 & 8,12 & $-10,92$ \\
\hline Paraguai & 5.319 & 11.692 & 5,96 & 11,86 & 54,51 \\
\hline Uruguai & 4.105 & 3.371 & 4,60 & 3,42 & $-21,77$ \\
\hline Chile & 6.864 & 2.060 & 7,69 & 2,09 & $-233,20$ \\
\hline Bolívia & 8.022 & 7.615 & 8,99 & 7,72 & $-5,34$ \\
\hline Peru & 2.558 & 4.984 & 2,86 & 5,05 & 48,68 \\
\hline América do Sul / Central & 5.209 & 6.763 & 5,83 & 6,86 & 22,98 \\
\hline América do Norte & 8.029 & 9.008 & 9,00 & 9,14 & 10,87 \\
\hline Europa & 24.532 & 22.874 & 27,49 & 23,21 & $-7,25$ \\
\hline África & 2.517 & 4.466 & 2,82 & 4,53 & 43,64 \\
\hline Ásia & 18.205 & 12.361 & 20,40 & 12,55 & $-47,28$ \\
\hline Japão & 3.361 & 4.822 & 3,76 & 4,89 & 30,30 \\
\hline Oceania & 45 & 260 & 0,05 & 0,26 & 82,69 \\
\hline Outros / Sem Especificação & 635 & 233 & 0,71 & 0,23 & $-172,53$ \\
\hline
\end{tabular}

Fonte: IBGE. Censos Demográficos 1991 e 2000 (tabulações especiais, Nepo/Unicamp apud PATARRA; BAENINGER, 2004).

de paz e segurança, e as situações de violações de direitos humanos como dimensões decisivas para o Plano de Ação.

O documento ressalta os efeitos positivos que a migração internacional pode assumir, tanto para as áreas de destino como para as áreas de origem. Para isso, incita os governos a analisarem as causas da migração, na tentativa de transformar a permanência num determinado país em opção viável para todos. No que se refere às remessas, preconiza seu incentivo mediante políticas econômicas e condições bancárias adequadas. Além disso, incentiva a migração temporária e o reforço do regresso voluntário de migrantes, e também enfatiza a necessidade de dados e informações adequadas.

São considerados três tipos de migrantes internacionais: migrantes documentados, migrantes não-documentados e refugiados/asilados. Quanto aos migrantes com documentação, os governos dos países recebedores de- vem considerar a possibilidade de lhes conceder, bem como aos membros de suas famílias, um tratamento regular igual ao concedido aos seus próprios nacionais, no que diz respeito aos direitos humanos básicos.

Quanto aos migrantes não-documentados, recomendase a implementação de ações que visem: reduzir seu número; evitar exploração e proteger seus direitos humanos básicos; prevenir o tráfego internacional com migrantes; e protegêlos contra o racismo, o etnocentrismo e a xenofobia.

Finalmente, o documento apela aos governos para que tomem medidas apropriadas para resolver conflitos, promovendo a paz e a reconciliação; que tenham respeito pelos direitos humanos e independência individual, assim como pela integridade territorial e a soberania dos Estados; e que aumentem seu apoio às atividades internacionais destinadas a proteger e a apoiar refugiados e migrantes. Os refugiados devem beneficiar-se do acesso a alojamento adequado, educação, contando com serviços de saúde que 
incluam planejamento familiar e outros serviços sociais necessários.

No Brasil, o Ministério das Relações Exteriores vem desenvolvendo ações sistemáticas de apoio consular aos brasileiros que vivem no exterior no que se refere à atualização de documentos, abertura dos consulados para a comunidade migrante, estímulo à formação de conselhos consulares com participação de cidadãos brasileiros que vivem fora do país (CNPD, 2001). Um prenúncio de formulação explícita de políticas públicas para a emigração pode ser considerado no documento produzido no I Encontro Ibérico da Comunidade de Brasileiros no Exterior, do qual resultou o Documento de Lisboa. ${ }^{11}$

É interessante considerar a lista de propostas finais aprovadas nesse Encontro, que inclui os elementos para a formulação de políticas públicas para a emigração, representação política para os emigrantes brasileiros, elaboração do estatuto dos brasileiros no exterior, situação de consulados e embaixadas brasileiras, além de apoio ao repatriamento, recadastramento eleitoral, reforço dos consulados itinerantes e assessoria jurídica a emigrantes. $^{12}$

No entanto, há que se registrar um viés econômico no trato com os emigrados. Na introdução desse documento, avalia-se entre 2 e 3 milhões de brasileiros vivendo no exterior, e já se menciona a questão das remessas - tema que, como já vimos, tem sido crescentemente discutido nos fóruns e debates a respeito dos grandes movimentos migratórios internacionais contemporâneos. Nesse caso, a questão das remessas é colocada como ponto de partida e sua justificativa se garante, em primeiro lugar, em nome da economia brasileira e, em segundo, pela questão social, pois considera-se que

Do ponto de vista da economia brasileira [...] a emigração é responsável pela remessa unilateral de cerca de dois bilhões de dólares anuais para o Brasil, contribuindo significativamente para diminuir o desequilíbrio da balança de pagamentos $e$, do ponto de vista social, para inclusão no mercado consumidor das famílias beneficiadas por essas remessas (Documentos de Lisboa, grifos da autora).

Também é interessante registrar que o Fundo Multilateral de Inversões - Fomin, do Banco Interamericano de Desenvolvimento - BID, vem realizando um

esforço conjunto com agentes governamentais, o setor privado e ONGs, instituições financeiras e outras, para aumentar a consciência da importância desses fluxos; aumentar a competição para diminuir os custos de remessas; promover a educação financeira, fomentar o impacto desses fundos ao oferecer mais opções financeiras para as famílias receptoras de remessas e suas comunidades (<http:// www.iadb.org.mif $>$ ). ${ }^{13}$

As autoridades vêm gradativamente se manifestando mais abertamente sobre o interesse desse montante de divisas para a economia nacional: percebe-se que o Brasil entrou no rol dos países com altos índices de remessas estimada em US\$ 5,8 bilhões em 2003. ${ }^{14}$ Destes últimos 5 bilhões que entraram no Brasil, o Japão é responsável por 3 bilhões; os USA, por 1 bilhão; e a Europa, por 1 bilhão - sendo que a metade desse volume vem de Portugal. Esse montante representa $7 \%$ das exportações brasileiras, que somaram 73 milhões, em 2003 - e é maior do que qualquer produto de exportação. Nesse último ano, as remessas são superiores às exportações de soja $(4,29$ bilhões), e bem mais elevadas do que os produtos tradicionais como o café (1,3 bilhão) e calçados (1,62 bilhão) (ROSSI, 2005), ou seja, como havia constatado Klagsbrunn (1996), o emigrante continua sendo o maior produto de exportação do Brasil.

Comemorando essa cifra que teria entrado no país em parte pelo Banco do Brasil e em outra trazida pessoalmente ou enviada por parentes e amigos, ${ }^{15}$ uma autoridade do Itamaraty manifestou-se, em tom jocoso: os brasileiros que vivem no exterior são compatriotas que deveriam ser recebidos com tapete vermelho, champanhe e caviar (Folha de S.Paulo, 4 jul. 2004).

\section{Estrangeiros no Brasil}

No que se refere à entrada de estrangeiros no Brasil, há que se registrar que o controle da imigração é uma atribuição de três ministérios: da Justiça, das Relações Exteriores e do Trabalho e Emprego. Ao Ministério da Justiça compete, essencialmente, o controle dos estrangeiros após sua entrada em território nacional e a aplicação da política de imigração - desde a concessão de visto, prorrogações, transformações de vistos, permanência, até medidas menos "simpáticas", como a extradição.

A política imigratória atual é orientada pela Lei no 6.815, de 19 de agosto de 1980, que desde o início de sua vigência vem sendo alvo de críticas no país. A lei criou ainda o Conselho Nacional de Imigração - CNI, órgão presidido pelo Ministério do Trabalho e Emprego, com representantes de vários outros ministérios, órgão de classe e Sociedade Brasileira para o Progresso da Ciência-SBPC. 
O CNI, por meio de 49 resoluções, orienta a política imigratória que, neste momento, privilegia a imigração sob o ponto de vista da assimilação da tecnologia, investimento de capital estrangeiro, reunião familiar, atividades de assistência, trabalho especializado e desenvolvimento científico, acadêmico e cultural (BARRETO, 2001).

Destaca-se ainda, na condução da política imigratória brasileira, o trabalho desenvolvido pelo Comitê Nacional para os Refugiados - Conare , vinculado ao Ministério da Justiça, que tem por finalidade a condução da política nacional sobre refugiados.

Cabe ao Ministério do Trabalho e Emprego estabelecer diretrizes e orientações de caráter geral no que concerne à autorização de trabalho a estrangeiros, com observância dos preceitos da Lei $\mathrm{n}^{-}$6.815/80 que define sua situação jurídica no país. ${ }^{16}$

Esse conjunto de dispositivos caracteriza o Brasil como um dos países mais restritivos quanto à imigração de estrangeiros. É interessante considerar as discussões a respeito no âmbito do governo do Mercosul, onde houve tentativas para harmonizar as políticas migratórias dos países-membros com vistas à livre circulação de trabalhadores no contexto da abertura comercial; nesse fórum, a posição brasileira tem-se mantido inalterada.

Outra dimensão que vem surgindo com ímpeto é a questão do acesso dos imigrantes não documentados e seus familiares aos serviços públicos no Brasil. Sabe-se que, no Brasil, crianças e adolescentes estrangeiros ou filhos de estrangeiros em situação ilegal nem sempre conseguem lugar em escolas públicas. No Fórum Social das Migrações, realizado em Porto Alegre, em janeiro de 2005, discutia-se o acesso desses migrantes às políticas universalistas - saúde e educação - constatando-se que o Sistema Único de Saúde - SUS é o único programa que, por sua regulamentação universalista, possui o respaldo de atendimento a todos, indistintamente.

No Brasil, os estados têm relativa autonomia no que se refere ao acesso de imigrantes e/ou seus filhos ao ensino público fundamental. No entanto, no plano jurídico, a Constituição Brasileira, de cunho universalista, contrapõese ao Estatuto do Estrangeiro, que é mais restritivo. Muitas vezes, o jovem pode freqüentar a escola, mas esta não pode emitir certificados de conclusão. ${ }^{17}$

Todas essas constatações a respeito dos movimentos migratórios internacionais a partir de e para o Brasil indicam fortemente a urgência de tratamento de uma problemática emergente que demanda análise, entendimento e monitoramento. Isso significa reformulação e ampliação das políticas e ações frente à nova situação, para alterar seus pressupostos, tomar em conta as especificidades dos fluxos e dos grupos sociais envolvidos, defender os indivíduos de atravessadores, ampliar seu escopo para dar conta dos direitos humanos dos migrantes e suas famílias. Sob a égide da Conferência sobre Direitos Humanos, o tratamento dos migrantes internacionais circunscreve-se no âmbito da articulação entre soberania nacional, democracia, direitos humanos e direitos ao desenvolvimento. O desafio consiste em transformar os compromissos assumidos internacionalmente em programas e práticas sociais condizentes com a articulação proposta - síntese das contradições, conflitos e antagonismos intensificados neste início de século. A migração internacional, que é a contrapartida populacional desse contexto globalizado, representa hoje a transformação da herança alvissareira do século 20 e um grande desafio para o século 21.

\section{NOTAS}

1. Veja-se, entre outros: Harvey (1993), Piore (1979), Benko e Lipietz (1998).

2. Veja-se Sassen (1988).

3. É bastante expressivo o montante e a qualidade da produção de demógrafos e especialistas em Estudos Populacionais sobre o tema. Mesmo com risco de apresentar lacunas, é importante mencionar o trabalho da Comissão de Migração Internacional da União Internacional para o Estudo da População - IUSSP. Cf., entre outros, Massey et al. (1993); a produção mexicana, consistente e numerosa, expressa-se nas variadas publicações da Somede; sugestivo também, o recente texto de Canales (2003). Um bom balanço da produção bibliográfica encontra-se em Assis e Sasaki (2001); contribuições posteriores mais significativas são mencionadas ao final.

4. À exceção de estudantes e casos isolados de profissionais de algumas áreas de ponta, a saída de brasileiros só existira durante o regime militar, com os refugiados políticos e expulsos do país.

5. O registro de brasileiros no exterior constitui um levantamento do Ministério das Relações Exteriores junto aos consulados e embaixadas brasileiras. Iniciou-se, em 1996, e já tivemos acesso a quatro levantamentos: além do primeiro, outros em 2000, 2001 e 2003. Cabe registrar aqui que não se trata de estatísticas públicas, mas sim de um levantamento administrativo interno; os próprios funcionários do Itamaraty são muito cautelosos no que se refere ao uso desses dados como uma quantificação precisa dos emigrantes brasileiros.

6. Nos últimos meses, a entrada de brasileiros nos Estados Unidos via México vem sendo amplamente noticiada e alardeada; na verdade, parece haver um afluxo mais intenso, possivelmente conjuntural e induzido. A mídia menciona a cifra de 800 mil a um milhão de brasileiros aí residindo, a maioria clandestinamente.

7. O caso dos movimentos populacionais entre Brasil e Paraguai tem sido amplamente estudado. Entre outros estudos, veja-se Palau (1995, 1996 e 1997) e Sprandel (1992 e 1998).

8. Considera-se, além da Argentina, Paraguai e Uruguai, também Chile, Bolívia e Peru. 
9. Ministério do Trabalho e Emprego. Secretaria de Relações do Trabalho (SRT)/Coordenação de Imigração (CGI), CNPD, (2000).

10. No âmbito das negociações que cercaram a conferência e que se encaminharam para o relatório final, dava-se ênfase às questões relacionadas à saúde reprodutiva e seus desdobramentos temáticos; no entanto, a questão das migrações internacionais geraram sempre fortes tensões entre os representantes dos países de origem e os dos países receptores, em grande parte identificados com movimentos internacionais de países pobres para países ricos. Nesse capítulo, o relatório reflete essas tensões, caracterizando-se por ambivalências, contradições e inexeqüibilidades. Apesar disso, constitui-se, como todos os relatórios das conferências da ONU, num referencial básico para discussões de ações e políticas no plano internacional, bem como norteador de financiamentos para pesquisa e, muitas vezes, ação.

11. O encontro foi promovido pela Procuradoria Regional dos Direitos do Cidadão do Distrito Federal - PRDC/MPF, com apoio organizacional da Casa do Brasil de Lisboa e a colaboração da Cáritas Portuguesa, da Cáritas Brasileira, da Obra Católica Portuguesa de Migrações e da Pastoral dos Brasileiros no Exterior da Conferência Nacional dos Bispos do Brasil, sob patrocínio do Banco do Brasil.

12. Há que se assinalar que, no já mencionado levantamento consular do Itamaraty de 2003, registra-se pela primeira vez a situação regular e irregular dos brasileiros no exterior, bem como os detentos nos respectivos países.

13. No Brasil, a iniciativa vem sendo organizada em conjunto com a Fundação Getúlio Vargas, com projeto coordenado pela pesquisadora Dra. Ana Cristina Braga Martes.

14. De acordo com os dados do BID, as remessas para o Brasil aumentaram significativamente, somando 2,6 bilhões, em 2001; 4,6 bilhões, em 2002; e 5,2 bilhões, em 2003.

15. O registro consular do Ministério das Relações Exteriores aponta, para 2003, 1,8 milhão de brasileiros vivendo no exterior. No entanto, o próprio Ministério chegou a uma estimativa de 2,5 milhões de emigrantes considerando estatísticas elaboradas pelos países que acolhem os brasileiros e dados referentes à movimentação consular dos brasileiros ilegais. Quanto às estimativas das remessas, o Banco do Brasil registrou o envio de 2,9 bilhões e o restante são quantias trazidas pessoalmente ao país ou enviadas por amigos.

16. Veja-se um levantamento sobre as atribuições dos Ministérios, bem como sobre as informações por eles obtidas e a regulamentação jurídica que informa essa atuação em Baeninger e Leoncy (2001).

17. Seminário 10 - Políticas Públicas. Fórum Social das Migrações (Porto Alegre, 23 a 25 de janeiro de 2005).

\section{REFERÊNCIAS BIBLIOGRÁFICAS}

ASSIS, G. de O.; SASAKI, E.M. Os novos migrantes do e para o Brasil: um balanço da produção bibliográfica. In: CNPD. Migrações internacionais - Contribuições para políticas. Brasília, DF: 2001. p. $615-669$.

BAENINGER, R.; LEONCY, C. Perfil dos estrangeiros no Brasil segundo autorizações de trabalho (Ministério do Trabalho e Emprego) e registro de entradas e saídas da Polícia Federal. In: CNPD. Migrações internacionais - Contribuições para políticas. Brasília, DF: 2001. p. 187-242.

BARRETO, L.P.T.F. Considerações sobre a imigração no Brasil Contemporâneo. In: CNPD. Migrações internacionais - Contribuições para políticas. Brasília, DF: 2001. p. 63-72.
BENKO, G.; LIPIETZ, A. As Regiões Ganhadoras. Portugal: Celta Ed., 1998.

CAFARDO, R. Educação, um direito do imigrante. $O$ Estado de S.Paulo, São Paulo, 20 mar. 2005. Caderno Vida, p. A-22.

CANALES, A. Demografía de la desigualdad. El discurso de la población en la era de la globalización. In: CANALES, A.; SIGAL, S.L. Desafíos teórico-metodológicos en los estudios de población en el inicio del milenio. México: El Colegio de México/Universidad de Guadalajara/Sociedad Mexicana de Demografía, Guadalajara, 2003. p. 43-86.

CARVALHO, J.A.M. de. O saldo dos fluxos migratórios internacionais no Brasil na década de 80: uma tentativa de estimação. In: PATARRA, N.L. (Coord.). Migrações Internacionais Herança XX Agenda XXI. Campinas: FNUAP, 1996. p. 217-226.

CASTELLS, M. A Sociedade em Rede. São Paulo: Paz e Terra, 1999.

CNPD. Migrações internacionais - Contribuições para políticas. Brasília, DF: 2001.

FNUAP. Resumo do Programa de Ação da Conferência Internacional sobre População e Desenvolvimento. Brasília. [s/d].

HARAZIM, D. Uma semana de cão. O Estado de S.Paulo, São Paulo, 20 mar. 2005. Caderno Aliás, p. J5.

HARVEY, D. A Condição Pós-Moderna. São Paulo: Loyola, 1993.

KLAGSBRUNN, V.H. Globalização da economia mundial e mercado de trabalho: a emigração de brasileiros para os Estados Unidos e Japão. In: PATARRA, N.L. (Coord.). Migrações Internacionais Herança XX Agenda XXI. Campinas: FNUAP, 1996. p. $33-48$.

MARTES, A.C.B. Brasileiros nos Estados Unidos: um estudo sobre imigrantes em Massachusets. São Paulo: Paz e Terra, 1999.

MASSEY, D. et al. Worlds in Motion: understanding international migration at the end of the millenium. Clarendon, Press Oxford, 1993.

MEDEIROS, J. Brasileiros nos Estados Unidos: sinal amarelo. $O$ Estado de S.Paulo, São Paulo, 20 mar. 2005. Caderno Cidades/ Metrópoles, p. C3.

OLIVEIRA, A.T. de. et al. Notas sobre a migração internacional no Brasil na década de 80. In: PATARRA, N.L. (Coord.). Migrações Internacionais Herança XX Agenda XXI. Campinas: FNUAP, 1996. p. 227-238.

PALAU, T. Migration among countries in Mercosul: trends and perspectives. Barcelona: IUSSP, May 7-10, 1997. Mimeografado.

Diagnóstico sobre residentes brasileños en el región oriental del Paraguay. Assuncion: OIM/Base Investigaciones Sociales, 1996.

Migrações transfronteiriças entre Brasil e Paraguai: o caso dos brasiguaios. In: PATARRA, N.L. (Coord.) Emigração e imigração internacionais no Brasil contemporâneo. Campinas: Programa Interinstitucional de Avaliação e Acompanhamento das Migrações Internacionais no Brasil; FNUAP, 1995.

PATARRA, N.L. Movimentos migratórios internacionais recentes de e para o Brasil e políticas sociais: um debate necessário. Fórum Social das Migrações. Porto Alegre: 2005. (No prelo).

PATARRA, N.; BAENINGER, R. Migrações Internacionais, Globalização e Blocos de Integração Econômica - Brasil no 
Mercosul. In: CONGRESSO DA ASSOCIAÇÃO LATINO-AMERICANA DE POPULAÇ̃̃O (ALAP), 1., Minas Gerais. Anais... 2004a.

. Mobilidade espacial da população no Mercosul: Metrópoles e Fronteiras. In: ENCONTRO ANUAL DA ANPOCS, 28., 2004, Caxambu. Anais... Belo Horizonte: Anpocs, 2004b.

Frontier and Migration in MERCOSUR: Meaning, Specificities and Implications. In: GENERAL POPULATION CONFERENCE, 24., 2001, Salvador. Anais... Salvador, Brasil: 2001. 29 p.

PIORE, M. Birds of Passage: Migrant Labour and Industrial Societies. New York: Cambridge University Press, 1979.

PIORE, M.; DOENINGER, H.P. Internal Labor Market and manpower analysis. Lexington: 1971.

PIORE, M.; SABEL, C. The second industrial divide: possibilities for prosperity. New York: Basic Books, 1984.

RABINOVICH, M. Brasil exportou um milhão de migrantes. O Estado de S.Paulo, São Paulo, 3 out. 1995.

ROSSI, P.L. Remessas de Emigrantes: pesquisa a Brasileiros em Portugal. Monografia (Bacharelado) - UFRJ/Instituto de Economia. Rio de Janeiro, abr. 2005.

SALES, T. Eles vestem o avental da América. O Estado de S.Paulo, São Paulo, 20 mar. 2005. Caderno Aliás, p. J4-5.

Migrações de fronteira entre o Brasil e os países do Mercosul. Revista Brasileira de Estudos de População, v. 13, n. 1, jan./jun. 1996.
SALES, T.; SALLES, M. do R. Políticas Migratórias: América Latina, Brasil e brasileiros no exterior. São Carlos: Ed. Sumaré, Edufiscar e Fapesp, 2002.

SASAKI, E.M. O jogo da diferença: a experiência identitária no movimento Dekassegui. Dissertação (Mestrado em Sociologia) IFCH/Unicamp, Campinas, 1998.

SASSEN, S. As cidades na economia mundial. São Paulo: Ed. Studio Nobel, 1998.

The Mobility of Labor and Capital. Cambridge, Cambridge University Press, 1988.

SPRANDEL, M. Brasileiros de além-fronteira: Paraguai. In: O fenômeno migratório no limiar do terceiro milênio: desafios pastorais. São Paulo: Vozes, 1998.

Brasiguaios: conflitos e identidade em fronteiras internacionais. Tese (Doutorado) - UFRJ, Rio de Janeiro, 1992.

Neide Lopes Patarra: Socióloga-Demógrafa; Professora Livre-Docente da Unicamp, Pesquisadora Titular da Escola Nacional de Ciências Estatísticas - ENCE/IBGE (patarra@ibge.gov.br).

Artigo recebido em 17 de maio de 2005. Aprovado em 1 de junho de 2005. 